Review

\title{
Negotiating the past, imagining the future: Israeli and Palestinian narratives in intergroup dialog
}

\author{
Andrew Pilecki*, Phillip L. Hammack \\ University of California, Santa Cruz, United States
}

\section{A R T I C L E I N F O}

\section{Article history:}

Received 25 August 2014

Accepted 25 August 2014

\section{Keywords:}

Narrative

History

Dialog

Contact

Future

Israeli-Palestinian conflict

\begin{abstract}
A B S T R A C T
Intergroup dialog affords an opportunity to study the deployment of historical narratives in conversation. In this field study, Israeli and Palestinian adolescents were randomly assigned to one of two conditions of intergroup dialog commonly in practice in intergroup encounter programs. In the coexistence condition, facilitators encouraged participants to focus on similarities and to construct a common ingroup identity. In the confrontational condition, facilitators encouraged participants to see themselves as group representatives and to become aware of power differences among groups. Our analysis examined variability in narrative content based on dialog condition and topical focus on either history or the imagined future. Using an interpretive analytical framework, we found that recognition of the outgroup narrative emerged among Jewish Israeli participants within the coexistence condition when the topic of an imagined future was discussed. Participants nevertheless struggled to reconcile divergent collective narratives in conversations about the past and a concrete future-namely, the conditions of a future peace agreement-regardless of the facilitation model employed. Findings are discussed in relation to theories of historical narrative in intergroup conflict and reconciliation, as well as distinct approaches to intergroup dialog.
\end{abstract}

(C) 2014 Elsevier Ltd. All rights reserved.

\section{Contents}

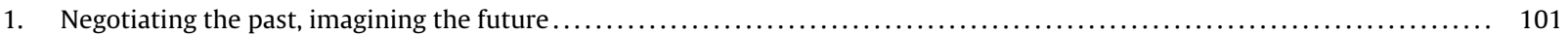

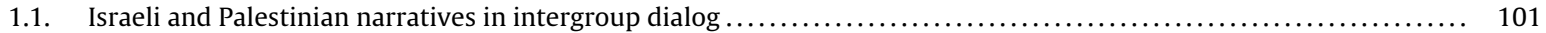

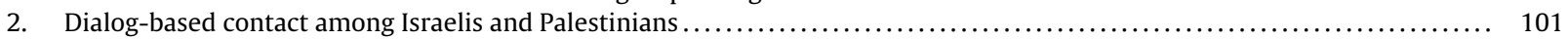

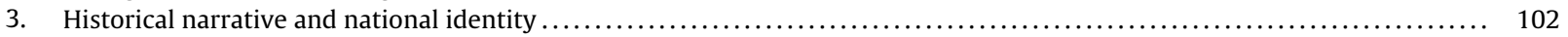

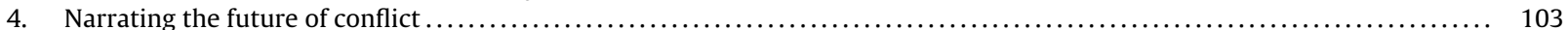

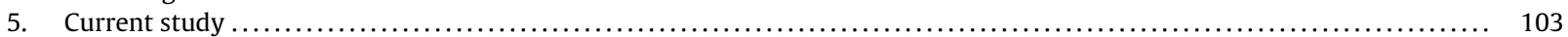

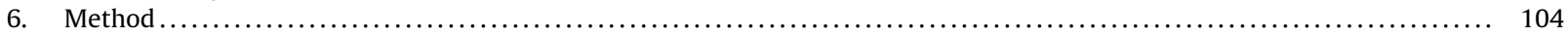

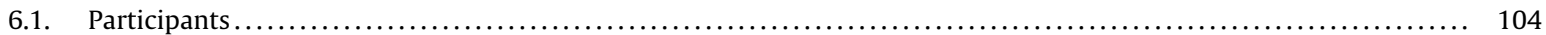

\footnotetext{
is This research was supported by a Faculty Research Grant from the Committee on Research of the Academic Senate, University of California, Santa Cruz, and by a National Academy of Education/Spencer Foundation Fellowship awarded to the second author. We greatly acknowledge the research assistance of Ella Ben Hagai, Neta Caspi, Tamar Dar, Aaron Dewey, Mofeda Dababo, Yaser Eid, Julian Farzan-Kashani, Ellen Garfield, Abigail Jacobson, Husam Jubran, Amelia Meloeny, Amber, Romano, Elena Ricks, Michelle Safi, Scott Silk, Michael Singh, Jerri Skog, Alex Strauss, Manal al-Tamimi, Eric Windell, and Megan Ziman. We would like to thank Elsamarie Corradetti for her comments on previous drafts of this manuscript.

* Corresponding author at: Department of Psychology, University of California, Santa Cruz, 1156 High Street, Santa Cruz, CA 95064, USA.

E-mail address: apilecki@ucsc.edu (A. Pilecki).
} 


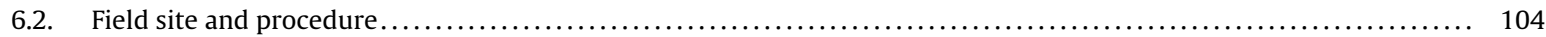

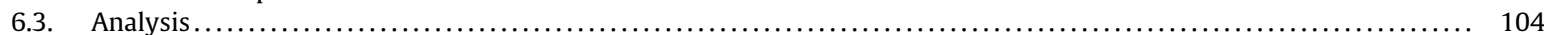

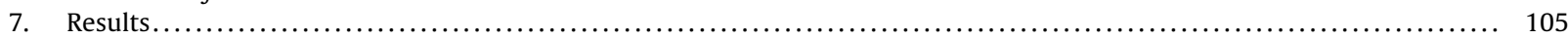

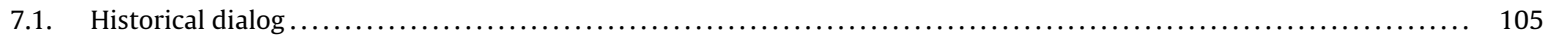

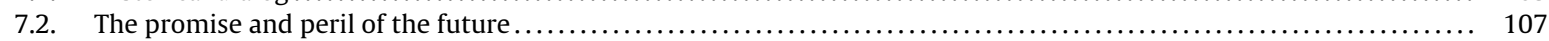

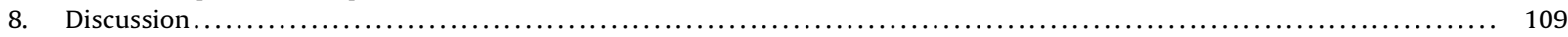

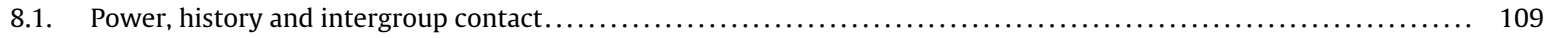

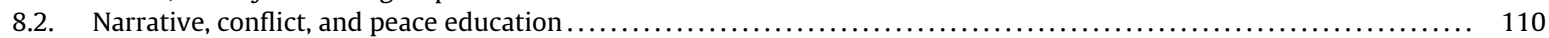

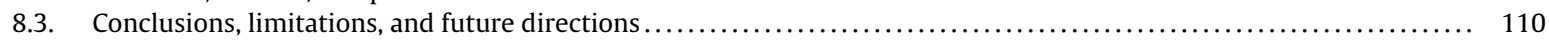

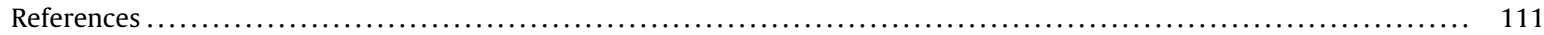

\section{Negotiating the past, imagining the future}

\subsection{Israeli and Palestinian narratives in intergroup dialog}

Within the Israel-Palestine conflict, the past is not merely prolog. More than six decades have passed since 1948, which for Israelis marks the birth of their nation and for Palestinians the loss of their vision of national self-determination. Yet, the memory of 1948 is kept alive by the imprint it has left on the collective (Jawad, 2006; Sa'di \& Abu-Lughod, 2007) and individual psyches (Bar-On, 2006; Hammack, 2006, 2008, 2011) of Israelis and Palestinians alike. Refugee camps, compulsory military service, checkpoints, and the persistent, underlying fear that whatever has been gained will ultimately be lost, and whatever has been sacrificed will ultimately be in vain, keep the events and consequences of 1948 fresh in the minds of those born long after their occurrence.

The historical narratives that Israelis and Palestinians construct regarding the past not only help explain the origins and development of the conflict up until the present time, but also legitimate past, present and future actions undertaken in the name of safeguarding the group or ensuring peace (Rotberg, 2006). Jewish Israelis and Palestinian hold contrasting accounts of the conflict's origin, its significant events, and the role each group has played within these events (Bar-Tal \& Salomon, 2006; Rouhana \& Bar-Tal, 1998). In addition, these narratives underlie processes of mutual identity denial (Kelman, 1999) and delegitimization (Oren \& Bar-Tal, 2007). Crucially, these contrasting views of history obstruct efforts to achieve peace (Kackowicz, 2004; Rouhana, 2004). Therefore, a key to understanding how the future course of the Israel-Palestine conflict is viewed is to examine how Jewish Israelis and Palestinians engage with and reproduce these polarized collective narratives.

To address this relationship between past and future, our study examined the historical and future narratives that emerge within the context of Jewish Israeli and Palestinian intergroup dialog. Using an interpretive, hermeneutic approach to discourse analysis common in narrative research and other studies of intergroup interaction (e.g., Bekerman, 2002, 2009b; Helman, 2002; Steinberg \& Bar-On, 2002), we sought to discover whether the reproduction of divergent historical narratives could be arrested within the intergroup contact setting. Our study thus addressed two research questions. First, can discussing the future, particularly a hypothetical, post-conflict future, facilitate the emergence of a shared collective narrative of the conflict between Jewish Israelis and Palestinians? Second, how does the dialog facilitation model affect the way in which youth engage with and reproduce collective narratives? In addressing these two research questions, our study adds to growing research illustrating the experiential process of intergroup contact (Pettigrew, 2008) as well as the potential effect of contact approach on this process (Hammack, Pilecki, \& Merrilees, 2013; Pilecki \& Hammack, 2013). Our study also demonstrates the relationship between how the past is viewed and prospects for peace in the future; thus our study not only aims to make a theoretical and empirical contribution to the literature but also inform the conduct of peace educators in the field.

\section{Dialog-based contact among Israelis and Palestinians}

Our study focused on dialog between Jewish Israeli and Palestinian youth participating in intergroup contact. Research investigating intergroup contact has proliferated since Gordon Allport's development of the contact hypothesis in 1954. Allport (1954) contended that contact between members of different groups in contexts characterized by equal status, institutional support, common goals and intergroup competition can result in reduced intergroup prejudice. Similarly, the Common Ingroup Identity Model (Gaertner \& Dovidio, 2000) emphasizes the role of common goals (Sherif, 1958) and the development of a common, superordinate identity in reducing prejudice. These approaches share the assumption that when members of different groups meet under favorable conditions they will encounter stereotype-disconfirming information and form affective ties (i.e., friendship) that will, in turn, lead to a reduction in negative intergroup attitudes (see Pettigrew, 1998). In practice, the implementation of this approach in intergroup encounters is termed the coexistence approach (Maoz, 2011).

Despite its widespread empirical support (see Pettigrew \& Tropp, 2006), criticism of the contact hypothesis and related frameworks has persisted. Early work by Yehuda Amir noted that application of the contact hypothesis in intergroup encounters consisting of Jewish and Arab Israelis would often exacerbate tension between groups (Amir, 1969) or result in positive effects for Jewish Israelis only (Amir, Bizman, Ben-Ari, \& Rivner, 1980). Encompassing much of the criticism that has been levied against intergroup contact research, Dixon, Durrheim, and Tredoux (2005) argued that contact research has focused 
too much on contact in ideal (i.e., "utopian") settings, has ignored the meaning that participants make of contact, and has placed too much on emphasis individual level processes (see also Hammack, 2009a).

In light of these limitations, particularly within contexts of intractable conflict like the Israeli-Palestinian conflict, alternative models of contact have been proposed. Pioneered by Rabah Halabi (see Halabi, 2004), the School for Peace approach seeks to capitalize on the aspects of intergroup contact viewed as obstacles by the traditional contact hypothesis. In practice, the implementation of this approach in intergroup encounters is termed the confrontational approach (Maoz, 2011). Halabi and Sonnenschein (2004a, 2004b) argue that contact should be viewed as the meeting between groups with distinct social identities rather than a meeting of separate individuals. As a meeting of social identities, the intergroup encounter becomes a forum through which processes of social competition are enacted and ingroup status is sought (see Tajfel \& Turner, 1986). As such, the power relations that characterize relations among groups on the macro level become reproduced within the micro level of the contact setting (see Maoz, 2000b, 2001; Suleiman, 2004).

Unlike the goals of the contact hypothesis, which seeks attitude change on the individual level, the School for Peace approach seeks to engender greater awareness about the conflict and the power relations among groups. Regarding the latter, the confrontational model has different goals for the members of the majority and the minority groups, respectively. While the confrontational model seeks to foster greater awareness among majority group members about their dominant position within the conflict, the confrontational model also seeks to empower members of the minority group by encouraging direct confrontation with majority group members. Rather than encouraging the development of a common ingroup identity, the confrontational model aims for the mutual differentiation of social identities (Hewstone \& Brown, 1986) by emphasizing-and directly challenging-the power relations that characterize the relations between groups in conflict.

Research examining differences between contact models has been limited. Hammack, Pilecki, and Merrilees (2013) found evidence that the goals of the confrontational model, particularly increased self-examination, awareness of intergroup difference, and acknowledgment of power asymmetries between groups, were reported by a sample of Israeli, Palestinian and US youth participating in dialog. Pilecki and Hammack (2013), however, found little difference in the historical narratives constructed by Israeli and Palestinian youth participating in dialog employing either a coexistence or confrontational model. Results revealed a common pattern across models; namely, both Israelis and Palestinians deployed historical narratives to compete for the title of "victim" within the conflict and gain the moral status that it entailed. Our study aims to build on this emerging body of research by examining whether discussing the future can be a means of transcending this dynamic and fostering the mutual recognition of collective narratives among Israelis and Palestinians.

\section{Historical narrative and national identity}

The focus of our study of intergroup dialog centers on how interlocutors engage with historical narratives of national identity across distinct models of dialog facilitation. Historical narratives serve key functions in intractable conflicts to legitimize the status quo and provide individuals with a sense of collective meaning and purpose (Hammack, 2008; Rouhana \& Bar-Tal, 1998). In the case of the Israeli-Palestinian conflict, which is characterized by the mutual denial (Kelman, 1999) and delegitimization (Oren \& Bar-Tal, 2007) of national identities, historical narratives are polarized (Rotberg, 2006). Given this context, discussions of history lend themselves to disagreement and the polarization of groups (Bekerman, 2002; Pilecki \& Hammack, 2013).

The fundamental link between history and national identity is rooted in the central role that historical narratives serve to provide the "common origins" upon which the "imagined community" of nationhood rests (Anderson, 2006). Historical narratives are representations of history that include a group's sense of what it is and what it should be; they thus provide the basis of group identity, norms and values as well as inform intergroup relations (Liu \& Hilton, 2005; see also László, 2013). They can also function as a legitimizing myth for the state (Liu, Fisher Onar, \& Woodward, 2014) and its political projects (see Klar, 2014). Collective historical narratives permeate all levels of the self-concept and facilitate the emotional bonds that tie the individual to the national collective (Liu \& László, 2007). As illustrated by Hammack (2009b, 2010a, 2010b), historical narratives provide not only the basis upon which national identity is understood and experienced but also the narrative construction of personal identity (Hammack, 2008; McAdams, 2006). Threats to the historical narrative, therefore, entail a threat to national identity and vice versa (see Liu, Fisher Onar, \& Woodward, 2014).

Mutually exclusive national identities rooted in divergent and clashing historical narratives persist within the context of the Israeli-Palestinian conflict given its lack of a resolution. Efforts to bridge this gap, namely to integrate Israeli and Palestinian historical narratives, have nevertheless been attempted, particularly within educational settings in Israel. Although Adwan and Bar-On (2004) describe the successful creation of a joint history textbook by a group of Jewish, Palestinian and international educators in the midst of the second Intifada (see also Bar-On \& Adwan, 2006), the application of shared history curricula illustrate the obstacles described above. In studies examining integrated Jewish-Palestinian bilingual schools in Israel, Bekerman and colleagues have found that, despite efforts to provide an integrated curriculum legitimizing both historical narratives, hegemonic and exclusivist collective narratives and identities inevitably emerged (Bekerman, 2008, 2009a; Bekerman \& Maoz, 2005; Bekerman \& Zembylas, 2010). Pilecki and Hammack (2013) discovered that, within the context of intergroup dialog, exclusivist narratives of history can facilitate processes of competitive victimhood as both groups emphasize instances of outgroup harm toward the ingroup.

Discussing history may be problematic if the aim of contact interventions is to foster tolerance, mutual understanding and common identity. Contexts of intergroup contact represent, from a critical junctures perspective, identity spaces within 
which collective narratives emerge and compete for legitimacy (see Liu et al., 2014). Given the current state of the conflict, recognizing the legitimacy of the rival narrative is tantamount to undermining ingroup identity and national goals, particularly for low status groups. As a "hot" topic of disagreement (Maoz, 2000b), history may be a topic either sought or actively avoided depending on group status. Ultimately, discussions of history may bind participants to their national identities and provoke collective processes characterized by mutual disagreement.

\section{Narrating the future of conflict}

Dialog featuring discussions of history within contexts of intractable conflict presents a conundrum for intergroup contact interventions. On the one hand, given the inextricable link between history and national identity, discussing history may facilitate the emergence of discourses featuring essentialized, exclusivist narratives (e.g., Bekerman, 2002; Helman, 2002). Discussing history may thus betray contact interventions, like those informed by the coexistence model (Maoz, 2011), that seek to develop a common ingroup identity. Avoiding history, on the other hand, may deprive participants, particularly those from low-status groups, the opportunity to convey collective narratives from which they derive meaning and strength (Barber, 2009; Hammack, 2010b). Avoiding history may also deprive participants of a key resource from which group identity may be articulated and distinguished within the contact setting, thereby betraying a key goal of interventions based on the confrontational model.

The "problem" of history within the intergroup contact setting has been dealt with in a number of ways. Interventions employing the narrative model (Maoz, 2011) emphasize the sharing of personal narratives, which may or may not feature historical content (Albeck, Adwan, \& Bar-On, 2002; Bar-On \& Kassem, 2004). Sharing personal narratives may, in a way, "personalize" historical content such that it becomes rooted in a personal rather than national identity. Taken from a realm marked by mutual identity denial and delegitimization, personal accounts of history may circumvent exclusivist constructions of national identity and provide space for the mutual recognition of suffering (Ron \& Maoz, 2013; Ron, Maoz, \& Bekerman, 2010). Personalizing history may nevertheless deprive participants of the benefits that collective narratives provide. Zembylas and Bekerman (2008), alternatively, argue that historical events of collective trauma that disrupt the status quo, what they refer to as "dangerous memories," can be used to challenge essentialist national identities and open space within the encounter for a group-based identity rooted in the collective experience of victimization. From a critical junctures perspective, dangerous memories constitute an alternate set of symbols and myths from which the legitimacy of the state and its political projects can be challenged (Liu et al., 2014). This strategy, however, requires participants to transcend their national identities and the narratives from which they emerge, which may be untenable within contexts of intractable conflict (Hammack, 2011).

Discussing a conflict's "future"-namely, its resolution and the state of relations in a post-conflict setting-may provide a means of overcoming intergroup relations marked by mutual denial and delegitimization. Ben-Hagai, Hammack, Pilecki and Arresta (2013) found that moving away from history might facilitate greater intergroup recognition. Specifically, they examined intergroup dialog among Jewish Israeli, Palestinian and US youth and compared discussion of the conflict's past versus the present. Results revealed that discussions of the present contained more moments in which the rival group narrative was recognized and more active involvement by the third-party (i.e., US participants). As noted by Buckley-Zistel (2006), identities are constructed in relation to both the past and the future. Discussing the "future," an abstract space in which hypothetical and idealized solutions to the conflict could be proposed, may provide an opportunity for participants in an intergroup encounter to transcend clashing narratives of the conflict, which may, in turn, provide an opportunity for a common identity or the mutual recognition of identities to emerge.

Featuring the "future" as a topic of discussion may thus provide a means to achieve the goals of specific models of intergroup contact. Providing space for members of rival groups to engage with de-essentialized, albeit hypothetical, constructions of national identity may further the goals of interventions guided by the coexistence model. Dialog in which participants outline a post-conflict setting might facilitate discussion about intergroup commonalities and shared goals and might help avoid "hot topics" that lead to disagreement and discord. This outcome, however, may again do a disservice to members of low-status groups who enter the contact setting with a desire to discuss matters of disagreement (Saguy, Dovidio, \& Pratto, 2008). Dealing with an abstract "future" may also betray the confrontational model's goal of addressing the reality of the conflict and the power relations among groups. As such, facilitators employing such a model may actively try to suppress dialog about the conflict's future.

\section{Current study}

Our study occurred in the naturalistic setting of an existing intergroup contact program that brought together Israeli, Palestinian, and US youth for two weeks of dialog. Following a similar epistemological and methodological approach to other research on existing intergroup encounters in the field (e.g., Bekerman, 2002; Helman, 2002; Maoz et al., 2002; Maoz, Bar-On, Bekerman, \& Jaber-Massawa, 2004), we employed an inductive, hermeneutic strategy in which the goal was to describe actual dialogic content as it emerged. Unique to our study, however, was an experimental design that allowed us to examine variability in dialog content based on the way in emerged across different facilitation models (coexistence versus confrontational) and topics (history versus future). Though we were able to vary the conditions of dialog in collaboration with program organizers and hence utilize an experimental design, our inductive approach led us to refrain from developing 
specific hypotheses about dialog content with regard to narratives. Our study was informed by an inductive epistemology concerned chiefly with "thick description" (e.g., Geertz, 1973) of a situation (i.e., intergroup contact). Our aim was thus to respond to calls for research on intergroup contact that interrogates the discursive content of such encounters in non-rarefied settings (Dixon et al., 2005).

\section{Method}

\subsection{Participants}

Our study consisted of 28 ( Age $_{\text {Median }}=17$ years; Age $_{\text {Range }}=14-18$ years) participants who were randomly assigned to dialog condition with consideration to balance national representation and sex among Jewish Israelis, Palestinian Israelis and Palestinians. The coexistence condition $(N=13)$ consisted of four Jewish Israelis (two females and two males), four Palestinians (two females and two males), one female Palestinian citizen of Israel and six US participants (two females and four males). The confrontational condition $(N=13)$ consisted of three Jewish Israelis (two female and 1 male), three Palestinians (one female and two male), one female Palestinian citizen of Israel, and six female US participants. Palestinian and Israeli participants were primarily recruited from schools in Israel and the occupied Palestinian territories (East Jerusalem and West Bank ${ }^{1}$ ) based on their interest in intergroup contact and English proficiency. US participants were recruited from Chicago and its surrounding suburbs. The orientation manual for participants framed the program as an educational opportunity for US participants, and they were encouraged to act as a third-party mediator within the dialog sessions.

Israeli and Palestinian participants traveled to the United States and resided with host families, many of whom were linked to the peace education program or had children participating in the program. The sample used in our study along with the number of participants is consistent with previous research on intergroup contact (e.g., Bekerman, 2002, 2009b; Maoz, 2001; Maoz et al., 2004).

\subsection{Field site and procedure}

To maximize relevance and applicability for existing intergroup encounters, our field study occurred within a US-based peace education program that brings Israeli, Palestinian, and US adolescents together for contact each summer. The program was structured as an intensive, two-week summer program comprised of daily two-hour dialog sessions, followed by educational (e.g., visits to a local mosque, synagogue and church) and leisurely activities in the Chicago area (e.g., visit to Navy Pier). Each dialog condition consisted of one Palestinian and Jewish facilitator, and sessions were conducted in English. Facilitation pairs in each condition were professionals trained in principles grounded in either the coexistence or confrontational model.

Four sessions, two on the topic of history and the two final sessions of the program-where discussion of the future was most likely to occur-were analyzed within each dialog condition. The activities employed by facilitators in each condition regarding historical dialog were similar. In the first historical dialog session of each condition, facilitators had participants meet with their national groups to construct historical timelines of the conflict, which were subsequently presented to the entire dialog group. Group discussion was not permitted during this session. Open discussion, however, was permitted in the second historical dialog session. It is worth noting that, as is characteristic of the confrontational model, facilitators of the confrontational model had participants meet in their uninational groups ${ }^{2}$ for the close of the second historical dialog session.

Facilitators differed in how the future of the conflict was dealt with across dialog conditions, however. The facilitators in the coexistence condition had participants share, both individually and with their national groups, what outcomes they desired in the conflict five and ten years into the future. Participants were also asked to identify concrete steps that they could take to help realize this future. Group discussion then followed. Facilitators in the confrontational condition, in contrast, permitted a free-flowing, unstructured discussion that touched upon many topics, one of which was the future of the conflict. Discussion was frequently punctuated with comments and reflection by the facilitators. The final session in both the coexistence and confrontational conditions closed with each participant given the opportunity to speak for five minutes to express their thoughts and feelings about the previous two weeks to the entire group.

\subsection{Analysis}

Every session during the two-week program was audio recorded and transcribed verbatim. Both authors were present at each session to record observational and ethnographic notes. Our ethnographic and observational notes informed the interpretive approach (Tappan, 1997) we used to analyze dialog session transcripts. The use of an interpretive analytical approach is common in research examining the process of intergroup contact (e.g., Bekerman, 2002; Helman, 2002; Maoz, 2000b). Our interpretive lens was informed by discursive analytical frameworks (Hammack \& Pilecki, 2014; Potter \& Wetherell, 1995)

\footnotetext{
${ }^{1}$ Participants from the Gaza Strip were not included due to mobility restrictions.

2 Discussion in the uninational meetings was not analyzed for this study given our interest in intergroup, rather than intragroup, dialog.
} 
that views text and talk as forms of social action employed for the purpose of constructing social categories and framing the nature of the relations among them (Edwards, 1991). This interpretive, constructivist analytical framework contrasts with more positivistic approaches to narrative research (e.g., László et al., 2013) and seeks to describe the discourse that emerges via intergroup dialog rather than make claims on emotional or cognitive processes on the individual level (e.g., László, Ehmann, Pólya, \& Peley, 2007).

We sought to identify in our analysis instances of narrative convergence and narrative divergence during intergroup dialog. For the purposes of our study, we defined narrative convergence as statements or exchanges in which the rival, outgroup narrative of the conflict is acknowledged and/or perceived as legitimate. Examples of convergence would include the recognition among Israeli participants of Palestinian claims to the land or Palestinian recognition of the need for a Jewish state. Narrative divergence, in contrast, refers to statements or exchanges in which the ingroup narrative is perceived as an authoritative account of the conflict and/or claims made within the rival, outgroup narrative are viewed as not being legitimate. Israeli claims that Palestinian refugees left under their own accord during the 1948 war or Palestinian claims that Israel is merely a European colonial project would represent examples of narrative divergence.

As is common in interpretive research, we employed an iterative analytical approach consisting of multiple close readings of session transcripts along with ethnographic and observational notes (e.g., Hammack, 2010c). We started our analysis by identifying instances of narrative convergence and divergence as they emerged within the session transcripts. We then examined these instances in relation to the ethnographic and observational data that we collected. Finally, we examined these instances within the larger context of the session transcript-particularly with respect to examples of convergence and divergence-to determine whether they represented isolated cases or major trends within the dialog session. These steps were repeated until coherent patterns of convergence and divergence emerged within each session we analyzed. Interpretive validity was determined via discussion and consensus among the authors (Tappan, 1997).

\section{Results}

We present our results in two sub-sections. In the first sub-section we review our findings comparing the discussion of history between Jewish Israeli and Palestinian youth in the coexistence condition to those in the confrontational condition. In the second sub-section, we review the results of our comparison between dialog conditions regarding discussion of the future. We present the results of our interpretive analysis using illustrative exchanges between participants. The presentation of our results thus reflects the inductive approach that we employed. These exchanges serve to highlight patterns of narrative divergence and convergence within the contact setting.

\subsection{Historical dialog}

Our analysis of historical dialog revealed a common pattern of narrative polarization between Jewish Israeli and Palestinian participants across dialog conditions. In both the coexistence and confrontational conditions, narrative divergence became evident in contestations over the meaning the 1948 war represented for both groups and its presentation to the thirdparty US audience. Within the Palestinian historical narrative, the 1948 war is referred to as al Nakba ("the Catastrophe"; Sa'di \& Abu-Lughod, 2007), while in the Israeli narrative it is referred to as the "War of Independence" (see Tessler, 1994). Within the "Nakba" narrative, the Palestinians are framed as victims of loss and dispossession (e.g., Said, 1979, 1994)-the outcome of the war framed as a devastation for Palestinian families, communities, and national aspirations. Within the "Independence" narrative, the war starts because of Palestinian rejection of the UN partition plan, the Jewish declaration of independence, and the subsequent declaration of war by Palestinians and neighboring Arab countries. Israel is thus positioned as the victim of Arab aggression in this narrative.

Within both dialog groups, Palestinian participants contended that Jewish aggression, in the form of continued and unlawful land acquisition, was the impetus behind the war. The fact that Jewish control over the former British Mandate of Palestine expanded to include areas that were assigned to Arab control in the UN Partition following the 1949 Armistice (Tessler, 1994) seemed to validate this belief in the eyes of Palestinians. In other words, Palestinian participants framed Jewish victory in the war within the larger narrative of Zionism as a colonial project to rule the entirety of Mandate Palestine (e.g., Rodinson, 1973). Jewish Israeli participants, in response, called upon traditional Israeli accounts of the 1948 war to justify Jewish participation in the war, as well as the expansion in territory that resulted:

$\operatorname{Ashraf}^{3}$ (16, M, Palestinian)

I'm not going to question that the partition plan stated that 55\% of the land [was] for Israelis. Why did they take $78 \%$ of the land?

Maayan (17, F, Jewish Israeli)

All right, so you don't need to agree with that [the partition plan]. You can. . .not agree with that. It's all right to not agree with something.... But then you started a war. ${ }^{4}$

\footnotetext{
${ }^{3}$ Pseudonyms have been given to all participants to protect their anonymity.

${ }^{4}$ We sought to present participant statements in a manner that enhances their readability while preserving the meaning. Toward this end, we use ellipses in place of words and word fragments uttered by participants.
} 
In this exchange in the coexistence group, Maayan addresses Ashraf's claims of dispossession resulting from Israeli expansion by asserting that Palestinians made a deliberate choice to initiate war in response to Jewish demands for autonomy, thereby reproducing a core element of the Israeli narrative of the war. This exchange illustrates the interplay of Israeli and Palestinian historical narratives, particularly the mutually exclusive claims to victimhood (Pilecki \& Hammack, 2013). The following exchange within the confrontational condition between Idan, a Jewish Israeli, and Wajdi, a Palestinian, further illustrates this dynamic ${ }^{5}$ :

Idan (17, M, Jewish Israeli)

Okay, no, no, no. The, the... Arab leadership, and the, the leaders of the Palestinians, said, "We will not recognize...a Jewish country, here, in, in this territory of Palestine. If there will be, if such a, a decision will be made in the United Nations, there will be a war, there will be a slaughter."

$\operatorname{Wajdi}$ (17, M, Palestinian)

I want, okay, can I say.

Idan

[Interrupts] So when, when ... the 1948 War started . . . and it started when the UN, decided that ... there will be two countries, not one Palestinian country [but] two countries, in Israel.

Wajdi

[Interrupts] Oh, that, can I say something?

Idan

And, no. No, wait a second. And, that's how the Nakba started. Because ... it's not that only we were allowed to declare a country. The Palestinians could [also] say, "Oh, now we're forming Palestine."

Like Maayan in the previous exchange, Idan argues that the 1948 war resulted from Palestinian and Arab intransigence, as well as their desire to destroy the nascent Jewish state. Thus, Israel's participation in the war is framed as a form of self-defense in the face of Arab/Palestinian aggression. Moreover, Palestinian victimization claims are undercut by Idan's depiction of the UN partition plan as a missed opportunity for Palestinians. Rather than attacking Israel, Palestinians could have agreed to form their own country. According to Idan, it is due to their decision to forgo this opportunity that the Nakba occurred. Thus, the Palestinians are ultimately responsible for the fate that befell them.

In addition, a historical narrative rooted in the claim that Palestinians were expelled as part of an active campaign by Jewish military forces during the 1948 war emerged among Palestinian participants in both conditions. For example, Sameera, a 17-year old Palestinian female in the confrontational condition, drew upon both the master Palestinian historical narrative as well as her family's historical narrative to illustrate this point:

Sameera (17, F, Palestinian)

But, I'm emotional, you're gonna understand that, I'm gonna let you understand as possible. Okay somebody, I think Sivan, ${ }^{6}$ said that the [Palestinians] who [emigrated] and fled to other countries were, like, well they were scared. They weren't scared. They were, my grandmother is a refugee. She came from Jaffa, from a village next to Jaffa called Yazur. Stephanie (17, F, US)

Where is that?

Sameera

It's now Israel ... So, my grandmother was sleeping in her house, the army came three o'clock in the morning, and I heard this story dozens of millions of times. They came to her house and made them all leave or they'll bomb the house, like, put explosives in the house. And they knocked down the door, and they made them go out. And they didn't know where to go, so they came to Tulkarm, which is now part of Palestine. That's one thing. Second of all, she still has the paper that proves that it is her house. But now it's a part of, I don't know what, [a] mall or something in Israel. That's one thing. And, I want to say, all the people who fled to other countries were not, most of them and ninety-nine percent were not, like, they wanted to. They were forced by force, by terror.

In this account Sameera makes the claim that Palestinians fled as a result of Jewish terror. Although discrepancies between this expulsion narrative and the oral histories of refugees have been noted (see Nets-Zehngut, 2011), Sameera nevertheless draws upon her grandmother's experience in the war to legitimize the expulsion narrative. In this case, the experience of Sameera's grandmother stands for the experience of all displaced Palestinians.

Within the traditional Israeli narrative of the war, Arabs who fled from what eventually became Israel did so because they were compelled to do so by Arab leaders who promised they would be able to return to their homes once the Israelis had been defeated. Refugees produced by the 1948 war were thus a product of misguided and overly optimistic Arab leaders and not a product of any actions undertaken by Jewish military forces, according to the Israeli narrative (see Nets-Zehngut,

\footnotetext{
5 Structured as a meeting among distinct groups rather than individuals, intra-group processes within intergroup dialog facilitated using the confrontational approach often result in the emergence of dominant voices who tend to reflect the sentiments within each national group (see also Maoz, Steinberg, Bar-On, \& Fakhereldeen, 2002) Idan and Wajdi emerged as the central actors for the Jewish Israeli and Palestinian groups, respectively, within the confrontational condition and are thus cited frequently in our discussion of our results.

${ }^{6}$ A female Jewish Israeli participant in the same dialog condition.
} 
2008; Tessler, 1994). In recent decades, though, this account has been challenged within scholarly and popular accounts in Israel. Revisionist histories that challenge the traditional Zionist narrative provide evidence for varying degrees of Jewish culpability in the expulsion of Palestinians (e.g., Morris, 1989; Pappé, 2007).

The exposure of the Jewish Israeli participants in this study to this revisionist account of history is unclear. The narrative that emerged among Jewish Israeli participants nevertheless offered explanations for the development of the Palestinian refugee problem:

Dana (16, F, Palestinian Israeli)

So if, if all over the history they lived there, they have the permission to destroy the houses of Palestinians that were living there?

Merav (16, F, Jewish Israeli)

They did? They did it?

Dana

They did that. In the beginning of the occupation. And I'm not saying that from [just the] Palestinian perspective. It was something that Jewish people confessed.

Merav

You know what, maybe. But, it was a war that it was...us or you.

In this exchange among participants in the coexistence condition, Dana suggests that Jews lived in Palestine throughout history. Jewish Israeli participants had stated this claim on a number of occasions in the dialog to legitimize Jewish ties to the land. According to Dana, though, this presence does not justify the expulsion of Palestinians from their homes during the war-an action that she claims, "Jewish people confessed." Merav's response suggests some possible validity to Dana's claim ("You know what, maybe"), but she then quickly mitigates Israeli responsibility ("But, it was a war that it was. ..us or you"). Merav's response to Dana is consistent with the Jewish Israeli historical narrative that levies ultimate responsibility for the Palestinian refugee at the feet of Arab leaders who attacked Israel. The action of Jewish forces in the 1948 war and its aftermath are framed within this narrative trope. If Jewish forces did act unjustly, it was specifically due to the circumstances placed upon them due to the Arab aggression that precipitated the 1948 war.

In sum, our interpretive analysis of dialog content revealed that participants across dialog conditions reproduced polarized historical narratives of the conflict. Historical narratives diverged among participants about the context and meaning of the 1948 war, with Jewish Israelis framing the war as the culmination of its quest for autonomy and independence, and Palestinians framing the war as an act of oppressive aggression.

\subsection{The promise and peril of the future}

Our analysis of dialog about the future revealed a more complex pattern of results. We found evidence for narrative convergence within the coexistence condition, however it was limited to Jewish Israeli participants and only when a hypothetical, post-conflict future was discussed. Palestinians in the coexistence condition, in contrast, narrated a future of empowerment. We also found that narrative divergence between Jewish Israeli and Palestinian narratives emerged, regardless of condition, when the discussion moved from a hypothetical point in the future to a more concrete discussion of the terms of any future settlement.

Jewish Israeli participants in the coexistence condition articulated a narrative of the future that ultimately led to the formation of two-states: one Jewish and one Palestinian. Remarking on the effect that the previous two weeks had on her, Merav, a 16-year-old Jewish Israeli female in the coexistence condition, noted:

... I think that [the peace education program] really changed me. Like, on both sides. In one hand it made me be much more Zionistic and believe in...the existence of Israel, and in the other hand, it made me know the other side... and to understand that we have. . to have two countries.

This narrative often included descriptions about the eventual dismantling of Israeli security measures such as the separation wall and checkpoints as well as the removal of Jewish settlements in the West Bank.

Palestinians in the coexistence condition, in contrast to Jewish Israelis, emphasized empowerment and resistance in their narrative of the future. This narrative, rather than featuring a recognition of Israeli claims, articulated a desire for a stronger, more unified government and better education:

Ashraf (16, M, Palestinian)

If we want to fight and resist this occupation, we should. . .get better education, and have more knowledge, because I think that it would be more effective than violence. ...

The Palestinian narrative of the future, as evidenced by Ashraf's statement, emphasized Palestinian empowerment, rather than mutual recognition.

Discussion about hypothetical points in the future were discouraged by the facilitators in the confrontational condition. Instances in which the conflict's future was discussed were therefore limited. Idan, a 17-year-old male Jewish Israeli, nevertheless offered a hypothetical proposal to the Palestinians: 
Would you, if I can now allow you to become citizens of Israel, you would not be denied your own education.... No one would deny you your language.... You would not be denied your prayers.... You would not be denied access to your holy sites.... And you will have total freedom of movement. Would you become citizens of Israel?

This hypothetical invitation to join Israel was subsequently followed by a counter-proposal from Wajdi, a 17-year-old male Palestinian:

I want to ask you the same question.... In Palestine. . .there are many Christians. They are living with us, we're living as Palestinians with each other, peacefully.... Why don't you become Palestinians?

In these excerpts, Idan and Wajdi give voice to a narrative in which Jewish Israelis and Palestinians live peacefully within one state. This hypothetical scenario is undercut, however, by the power implicated in the invitation. Acceptance of the proposal by the invitee would imply that the inviter has the legitimacy to make such a proposal in the first place, thereby recognizing the inviter's claim to the land.

This interaction between Idan and Wajdi reflected a common pattern of narrative divergence across dialog conditions when discussion about the future shifted from a hypothetical point in the future to the actual conditions of any future peace agreement. This divergence between Jewish Israeli and Palestinian narratives hinged primarily on the issue of Palestinian rights versus the need for Israeli security. As noted, Jewish Israeli participants were more likely to articulate a narrative of the future marked by a two-state solution and the dismantling of Israeli security measures that Palestinians find oppressive. This vision, as illustrated in the following exchange in the coexistence condition, was predicated on Palestinians relinquishing their armed struggle:

Yuval (17, M, Jewish Israeli)

...If there will be a ceasefire... I think everyone wants a ceasefire, it can be a positive thing. . .to close the checkpoints. Dana (16, F, Palestinian Israeli)

But when we talk about ceasefire, we talk about, for example, no missiles [being] thrown into Sderot. At the same time, the occupation, and the checkpoints, like everything, will be continued inside Palestine. So I don't know how much the ceasefire can help a kind of peace.

Merav (16, F, Jewish Israeli)

It can, because in like, it depends on the time, I mean if it's a ceasefire that continues... Israel will see that maybe the checkpoints and all the occupation are not necessary anymore. But again, we will have to have trust.

The primary obstacle to peace within the Jewish Israeli narrative is Palestinian violence; once this threat is removed, the security measures and settlements that Palestinians find oppressive will be removed, and the path would be opened to a Palestinian state. Jewish Israelis participants often justified this position by pointing to historical examples of Arab aggression. As evidenced by Dana's objection however, there is a lack of trust that such an outcome would occur. The emphasis placed on Palestinian violence as the primary obstacle to peace represents an important trope in the current Jewish Israeli narrative of the conflict, particularly after Benjamin Netanyahu became Prime Minister of Israel in February 2009. Moreover, as illustrated by Bar-Tal, Halperin, and Oren (2010), although there is a general agreement within Israel regarding a two-state solution, there is less support for specific compromising measures (e.g., partition of Jerusalem; see also Bar-Tal, 2004b).

The Palestinian narrative regarding a future settlement reverses this relationship between Israeli security measures and Palestinian violence:

Wajdi (17, M, Palestinian)

Do you remember-you may ask your father or your mother or your grandfather, whatever. At the beginning of the [19]70s, in the beginning of the [19]80s, there [was] peace....between Palestine and Israel, and Fatah and Hamas [existed] in these times. And from [19]93 to 2000, there [was] peace. . . and there were. . .no rockets. . .because there were less checkpoints and there were no military operations each night.... So when you decrease the number of checkpoints so and release some of the prisoners, the refugees, when you solve these things-I'm talking about the Israeli government-when you solve these things, peace will be inevitable.

Wajdi constructs a historical narrative in his statement in order to justify the Palestinian position regarding the conditions of a future agreement. Because periods of peace between Israelis and Palestinians were accompanied by fewer security measures, the removal of these measures in the future would similarity bring about peace. This reflects the larger Palestinian position requiring conditions (i.e., settlement freeze) prior to any discussion of a peace agreement (e.g., Khoury \& Hass, 2013).

When put in concrete terms, "peace" became a matter of contention fueled by the emergence of mutually exclusive collective narratives. This mutual lack of recognition may have, in turn, decreased the willingness of participants to recognize the claims made by outgroup members. This outcome was reflected in Idan's closing statement to the dialog group:

The Palestinian group, I don't know, I feel it's just one narrative. Like, all the Palestinian people are always poor, are always under oppression, and they couldn't possibly ever...could never do anything wrong. ... And that point just pissed me off so much in the last session [that] I just threw the whole pluralist idea out the window and just said [what I] believe. 
The perceived unwillingness of the Palestinian delegation to recognize any aspect of the Israeli historical narrative was a source of frustration for Idan and, as he described, made him even more unwilling to recognize the legitimacy of Palestinian claims. Discussion of history in previous sessions, therefore, may have primed the emergence of divergent narratives when discussing the future.

\section{Discussion}

Our study sought to address the question of narrative convergence and divergence in dialog about history and the future among Israeli and Palestinian youth motivated to pursue intergroup contact. Fusing field experimental, ethnographic, and interpretive methods, we examined intergroup contact using two distinct models of dialog facilitation: one that encouraged common ingroup identity construction (the coexistence model), and one that encouraged mutual differentiation and recognition of distinction (the confrontational model). Though common in the practice of peace education and conflict resolution, comparative studies of these models have been virtually non-existent (see Hammack et al., 2013; Pilecki \& Hammack, 2013). We thus sought to elucidate for peace educators the potential configuration of facilitation approach and dialog topic that most effectively arrests the processes of mutual identity denial and narrative polarization that characterizes the Israeli-Palestinian conflict.

Our findings revealed the sustenance of polarized historical narratives about the origins of the conflict. Across both conditions of dialog, youth reproduced historical narratives of the 1948 war that largely failed to acknowledge the legitimacy of the counter-narrative. Discussions about a hypothetical future appeared to create narrative convergence, but only for Jewish Israeli participants in the coexistence condition. Once dialog shifted, however, from the hypothetical to the concrete in terms of actual conflict resolution, a mutual lack of recognition emerged in both conditions.

Our findings illustrate that the experiential process of intergroup contact is shaped in large part by the divergent, mutually exclusive narratives that define the intractability of the Israel-Palestine conflict (see Rotberg, 2006). Jewish Israeli and Palestinian participants reproduced dominant tropes of their respective group's collective narratives within the dialog space. Victimization and dispossession emerged within the Palestinian narrative of the conflict's history and future (see Hammack, 2010a), while Jewish Israelis emphasized their own history of victimization in their narrative, which ultimately informed and justified their emphasis on the importance of security and defense in negotiating a future settlement. It is noteworthy that this pattern of results emerged within groups employing different facilitation models of intergroup contact. We interpret our findings in light of the point to the limitations of intergroup contact interventions in contexts of power asymmetry and intractability.

\subsection{Power, history and intergroup contact}

The persistence of divergent collective narratives represents a particularly notable obstacle to facilitation models that seek to develop a common ingroup identity. Given the duration and centrality of the Israel-Palestine conflict (Bar-Tal, 2007), participants in our study were able to draw upon numerous instances in which the rival group had victimized them. An unjust act, Shnabel and Nadler (2008) note, creates a moral "debt" that the perpetrating group must "pay" in a manner and time of the victim's choosing. This situation, paradoxically, puts the victim in a position of power due to the moral status that being a victim confers while the perpetrator is placed in a position of identity threat. Occupying both of these roles, groups in conflict often jockey for the role of ultimate "victim" in the conflict to obtain the moral status that it entails, a process that Noor and colleagues (2012) call intergroup competitive victimhood (see also Pilecki \& Hammack, 2013; Vollhardt, 2009).

As illustrated in our study, discussing history lent itself to the emergence of divergent narratives and a lack of mutual recognition. To admit that one's group treated another group unjustly would be to effectively cede moral status to the rival group and the power implied therein. Jewish Israeli and Palestinian participants employed various strategies to avoid this outcome. Palestinians, for example, rarely recognized the legitimacy of Jewish Israeli victimhood claims. This lack of recognition was met with consternation among Jewish Israeli participants, who, in turn, presented a historical narrative emphasizing the magnitude of their own victimization (i.e., the Holocaust) and providing justification for Jewish Israeli actions toward Palestinians (see Klar, Schori-Eyal, \& Klar, 2013; Wohl \& Branscombe, 2008). As evidenced in our study, recognizing the rival narrative within the contact setting threatens the moral status of the ingroup and undercuts the struggle that gives national identity meaning.

Beyond the power implicit in the victim-perpetrator relationship, Jewish Israelis and Palestinians enter the context of intergroup contact with statuses afforded to them as a result of their national identities. Recent research on the role of group status in intergroup contact reveals the distinct objectives of group members. Members of high-status groups tend to favor discussion about intergroup commonalities, while members of low-status groups favor discussion about intergroup differences (Saguy et al., 2008). This desire to discuss status differentials becomes stronger the more that group-based hierarchies are perceived to be illegitimate (Saguy \& Dovidio, 2013). The perception among advantaged group members that their group has been wronged, moreover, increases their unwillingness to recognize historical injustice perpetrated against other groups (Saguy, Chernyak-Hai, Andrighetto, \& Bryson, 2013; see also Klar, 2014, Wohl \& Branscombe, 2008). We observed many of these status-based processes in our study, which may have contributed to the overall divergence of Jewish Israeli and Palestinian narratives. 
As members of an occupied, low-status group, Palestinian participants emphasized the distinctiveness of their collective narrative and the desire for recognition. This narrative, featuring accounts of massacres, dispossession, and collaboration with foreign nations on behalf of the Israelis serves to delegitimize Israel's advantaged position in the conflict. As voiced by Idan's closing remarks, many Jewish Israeli participants, embodying their high-status position (see Saguy et al., 2008), entered the contact setting with the objective to establish a common ground with Palestinians rooted in a collective desire for peace. When it became evident that the Palestinian agenda was distinct (see Maoz, 2000a), Jewish Israeli participants engaged in processes of competitive victimhood and justification to maintain their moral status within the group (see Pilecki \& Hammack, 2013). Emphasizing the wrongs they endured over the course of the conflict may have, in turn, made Jewish Israelis even more unwilling to recognize aspects of the Palestinian narrative, thereby exacerbating the divergence in narratives emerging within the contact setting. These contrasting historical narratives were then used by the participants to inform their contrasting stances regarding any future peace settlement. Interpreted as such, our findings illustrate how narratives are shaped by issues of power within the contact setting.

\subsection{Narrative, conflict, and peace education}

Our study interrogated the possibility of narrative reconciliation in the midst of an existing peace education program. Hence our findings are closely linked to ongoing practices in the field. The coexistence model directly encourages narrative reconciliation by seeking to instill a common ingroup identity among interlocutors (Maoz, 2011). Rather than reconciliation or convergence, the confrontational model encourages mutual narrative recognition for the purposes of challenging the power asymmetries that help maintain a state of conflict (Maoz, 2011).

The results of our study reveal the dialogic content these distinct models invoke. Whereas narratives remained polarized across dialog conditions when history was discussed, the convergence of intergroup narratives did emerge more prominently within the coexistence condition when the topic of discussion moved to a hypothetical, post-conflict point in the future. Facilitators within the confrontational condition did not encourage participants to talk about the future. When the future did come up, rather, it was during the course of a free-flowing conversation among participants. This finding is not surprising, as the confrontational model aims to have participants confront and engage with the realities of the conflict; intentional discussion of a hypothetical point in the future would betray this goal.

What was noteworthy was how quickly narratives became polarized across dialog conditions when a more proximal event in the future, namely the details of a peace agreement, was discussed. Trope and Liberman (2000) note that a person's construal of a future event is shaped more by the concrete and incidental details of that event-and less by abstract features-as the temporal distance from that event decreases. This process may explain the common pattern of discourse we observed across dialog conditions. The details of a peace accord between Israelis and Palestinian, in other words, became more prominent within the discussion given that it exists in a more immediate point in the future in comparison to a hypothetical, post-conflict period. These details, rooted in fundamental concerns over Israeli security and Palestinian civil rights, facilitated disagreement and narrative divergence between Jewish Israeli and Palestinian participants.

The results of our study reveal that discussing a hypothetical, post-conflict future may help bring groups together, albeit in a circumscribed manner. Our study reaffirms previous research (Hammack et al., 2013; Pilecki \& Hammack, 2013) illustrating the limits of the coexistence-based contact model to arrest the process of narrative polarization that characterizes the IsraeliPalestinian conflict on a macro level. As a matter of practice, we would caution peace educators to closely evaluate the goals of their intervention and reflect upon whether discussing the future helps to achieve these goals. Our study illustrates that discussing the future, particularly a hypothetical state of peace, may not act as an adequate salve to the inherent dilemmas that peace education interventions in the midst of intractable conflict face.

\subsection{Conclusions, limitations, and future directions}

Following the theoretical premise that history is codified through the construction and deployment of narrative (Hammack, 2008; Liu \& Hilton, 2005), our study interrogated the way in which young Palestinians and Israelis engaged with narratives in discussions about the past and future. Our interpretive analysis of dialog in two distinct conditions revealed the endurance of historical narratives that justify and legitimize the status quo of conflict and inequality between Palestinians and Israelis. Hence our study revealed the reproductive role intergroup dialog can have in settings of high intractability, regardless of the type of dialog facilitated. These findings add to the growing chorus of scholars and practitioners who recognize that the principles, aims, and rationales for different models of intergroup contact and peace education must be more clearly articulated and implemented in practice (e.g., Bekerman \& Maoz, 2005; Hammack, 2009a, 2011; Maoz, 2011).

Our study was limited by its focus on a single program and hence we cannot generalize our findings to other types of contact encounters or peace education interventions. The fact that dialog sessions were conducted in English, a non-native language for a majority of participants, is worth noting. Scholars have pointed out that the privileging of one language-in most cases Hebrew-can exacerbate power asymmetries within the contact setting (Halabi \& Sonnenschein, 2004b; Halabi \& Zak, 2004). The use of a common, third-party language may therefore be advantageous within the dialog setting.

Future studies might expand in scope to examine different types of programs (e.g., regional versus non-regional based). In addition, because our study occurred in the field, there were aspects beyond our control (e.g., specific facilitator interventions, impact of contact outside the dialog session). Studies of intergroup contact conducted in laboratory settings are considered 
less ideal than those conducted in the field (Dixon et al., 2005), but the use of different methodologies to examine similar questions related to narrative engagement would provide converging evidence for particular phenomena.

In spite of its limitations, our study provides much-needed "thick description" of the actual content of contact (Dixon et al., 2005). Our design and analysis moves beyond the individual as unit of analysis to consider the dialog process itself. Our study thus adds to a growing literature documenting the process of intergroup contact, particularly within the context of the Israeli-Palestinian conflict (e.g., Abu-Nimer, 1999; Bekerman, 2002; Helman, 2002; Maoz, 2000b; Maoz et al., 2002, 2004). Given that the structural conditions that create conflict and prejudice rely upon narratives for maintenance, meaning, and adherence, it stands to reason the research that can directly study narratives as they are deployed in interaction is needed. Our study represents one such attempt to link collective narratives to intergroup processes through the study of dialog as it naturally unfolds in conversation between groups in conflict.

\section{References}

Abu-Nimer, M. (1999). Dialogue, conflict resolution and change: Arab-Jewish encounters in Israel. Albany, NY: State University of New York Press.

Adwan, S., \& Bar-On, D. (2004). Shared history project: A PRIME example of peace-building under fire. International Journal of Politics, Culture and Society, 17(3), 512-513.

Albeck, J. H., Adwan, S., \& Bar-On, D. (2002). Dialogue groups: TRT’s guidelines for working through intractable conflicts by personal storytelling. Peace and Conflict: Journal of Peace Psychology, 8(4), 301-322.

Allport, G. W. (1954). The nature of prejudice. Reading, MA: Addison-Wesley.

Amir, Y. (1969). Contact hypothesis in ethnic relations. Psychological Bulletin, 71(5), 319-342.

Amir, Y., Bizman, A., Ben-Ari, R., \& Rivner, M. (1980). Contact between Israelis and Arabs: A theoretical evaluation of effects. Journal of Cross-Cultural Psychology, 11(4), 426-443.

Anderson, B. (2006). Imagined communities: Reflections on the origins and spread of nationalism (Rev. Ed.). New York: Verso.

Barber, B. K. (Ed.). (2009). Adolescents and war: How youth deal with political violence. New York: Oxford University Press.

Bar-On, D., \& Adwan, S. (2006). The psychology of better dialogue between two separate but interdependent narratives. In R. I. Rotberg (Ed.), Israeli and Palestinian narratives in conflict: History's double helix (pp. 205-224). Bloomington, IN: Indiana University Press.

Bar-On, D., \& Kassem, F. (2004). Storytelling as a way to work through intractable conflicts: The German-Jewish experience and its relevance to the Palestinian-Israeli context. Journal of Social Issues, 60(2), 289-306. http://dx.doi.org/10.1111/j. 0022-4537.2004.00112.x

Bar-On, M. (2006). Conflicting narratives or narratives of a conflict: Can the Zionist and Palestinian narratives of the 1948 war be bridged? In R. I. Rotberg (Ed.), Israeli and Palestinian narratives of conflict: History's double helix (pp. 142-173). Bloomington, IN: Indiana University Press.

Bar-Tal, D. (2004). The necessity of observing real life situations: Palestinian-Israeli violence as a laboratory for learning about social behaviour. European Journal of Social Psychology, 34, 677-701. http://dx.doi.org/10.1002/ejsp.224

Bar-Tal, D. (2007). Sociopsychological foundations of intractable conflicts. American Behavioral Scientist, 50(11), 1430-1453. http://dx.doi.org/10.1177/0002764207302462

Bar-Tal, D., Halperin, E., \& Oren, N. (2010). Socio-psychological barriers to peace making: The case of the Israeli Jewish society. Social Issues and Policy Review, 4(1), 63-109. http://dx.doi.org/10.1111/j. 1751-2409.2010.01018.x

Bar-Tal, D., \& Salomon, G. (2006). Israeli-Jewish narratives of the Israeli-Palestinian conflict: Evolution, contents, functions and consequences. In R. I. Rotberg (Ed.), Israeli and Palestinians narratives of conflict: History's double helix (pp. 19-46). Bloomington, IN: Indiana University Press.

Bekerman, Z. (2002). The discourse of nation and culture: Its impact on Palestinian-Jewish encounters in Israel. International Journal of Intercultural Relations, 26, 409-427.

Bekerman, Z. (2008). The complexities of teaching historical conflictual narratives in integrated Palestinian-Jewish schools in Israel. International Review of Education, 55(2-3), 235-250. http://dx.doi.org/10.1007/s11159-008-9123-y

Bekerman, Z. (2009a). Identity versus peace: Identity wins. Harvard Educational Review, 79(1), 74-83.

Bekerman, Z. (2009b). Identity work in Palestinian-Jewish intergroup encounters: A cultural rhetorical analysis. Journal of Multicultural Discourses, 4(2), 205-219. http://dx.doi.org/10.1080/17447140902741304

Bekerman, Z., \& Maoz, I. (2005). Troubles with identity: Obstacles to coexistence education in conflict ridden societies. Identity: An International Journal of Theory and Research, 5(4), 341-358. http://dx.doi.org/10.1207/s1532706xid0504_3

Bekerman, Z., \& Zembylas, M. (2010). Fearful symmetry: Palestinian and Jewish teachers confront contested narratives in integrated bilingual education. Teaching and Teacher Education, 26(3), 507-515. http://dx.doi.org/10.1016/j.tate.2009.06.010

Ben Hagai, E., Hammack, P. L., Pilecki, A., \& Aresta, C. (2013). Shifting away from a monolithic narrative on conflict: Israelis, Palestinians, and Americans in conversation. Peace and Conflict: Journal of Peace Psychology, 19(3), 295-310. http://dx.doi.org/10.1037/a0033736

Buckley-Zistel, S. (2006). In-between war and peace: Identities, boundaries and change after violent conflict. Millennium: Journal of International Studies, 35(1), 3-21. http://dx.doi.org/10.1177/03058298060350010101

Dixon, J., Durrheim, K., \& Tredoux, C. (2005). Beyond the optimal contact strategy: A reality check for the contact hypothesis. American Psychologist, 60(7), 697-711.

Edwards, D. (1991). Categories are for talking: On the cognitive and discursive bases of categorization. Theory Es Psychology, 1(4), 515-542.

Gaertner, S. L., \& Dovidio, J. F. (2000). Reducing intergroup bias: The common intergroup identity model. New York: Psychology Press.

Geertz, C. (1973). The interpretation of cultures and selected essays. New York: Basic Books.

Halabi, R. (Ed.). (2004). Israeli and Palestinian identities in dialogue: The school for peace approach (D. Reich, trans.). New Brunswick, NJ: Rutgers University Press.

Halabi, R., \& Sonnenschein, N. (2004a). Awareness, identity, and reality: The school for peace approach. In R. Halabi (Ed.), Israeli and Palestinian identities in dialogue: The school for peace approach (pp. 47-58). New Brunswick, NJ: Rutgers University Press.

Halabi, R., \& Sonnenschein, N. (2004b). The Jewish-Palestinian encounter in a time of crisis. Journal of Social Issues, 60(2), 373-388.

Halabi, R., \& Zak, M. (2004). Language as a bridge and an obstacle. In R. Halabi (Ed.), Israeli and Palestinian identities in dialogue: The school for peace approach (pp. 141-158). New Brunswick, NJ: Rutgers University Press.

Hammack, P. L. (2006). Identity, conflict, and coexistence: Life stories of Israeli and Palestinian adolescents. Journal of Adolescent Research, 21(4), 323-369.

Hammack, P. L. (2008). Narrative and the cultural psychology of identity. Personality and Social Psychology Review, 12(3), $222-247$. http://dx.doi.org/10.1177/1088868308316892

Hammack, P. L. (2009a). The cultural psychology of American-based coexistence programs for Israeli and Palestinian youth. In M. Zembylas, Z. Bekerman, \& T. Gallagher (Eds.), Peace education in conflict and post-conflict societies: Comparative perspectives (pp (pp. 127-144). New York: Palgrave Macmillan.

Hammack, P. L. (2009b). Exploring the reproduction of conflict through narrative: Israeli youth motivated to participate in a coexistence program. Peace and Conflict: Journal of Peace Psychology, 15(1), 49-74. http://dx.doi.org/10.1080/10781910802589923

Hammack, P. L. (2010a). The cultural psychology of Palestinian youth: A narrative approach. Culture E Psychology, 16(4), 507-537. http://dx.doi.org/10.1177/1354067X10380159

Hammack, P. L. (2010b). Identity as burden or benefit? Youth, historical narrative, and the legacy of political conflict. Human Development, 53, $173-201$. http://dx.doi.org/10.1159/000320045 
Hammack, P. L. (2010c). The political psychology of personal narrative: The case of Barack Obama. Analyses of Social Issues and Public Policy, 10(1), $182-206$.

Hammack, P. L. (2011). Narrative and the politics of identity: The cultural psychology of Israeli and Palestinian youth. New York: Oxford University Press.

Hammack, P. L., \& Pilecki, A. (2014). Methodological approaches in political psychology: Discourse and narrative. In T. Capelos, H. Dekker, C. Kinnvall, \& P. Nesbitt-Larking (Eds.), Palgrave handbook of global political psychology (pp. 79-98). New York: Palgrave Macmillan.

Hammack, P. L., Pilecki, A., \& Merrilees, C. (2013). Interrogating the process and meaning of intergroup contact: Contrasting theoretical approaches. Journal of Community \& Applied Social Psychology, http://dx.doi.org/10.1002/casp.2167

Helman, S. (2002). Monologic results of dialogue: Jewish-Palestinian encounter groups as sites of essentialization. Identities: Global Studies in Culture and Power, 9, 327-354.

Hewstone, M., \& Brown, R. (1986). Contact is not enough: An intergroup perspective. In M. Hewstone, \& R. Brown (Eds.), Contact and conflict in intergroup encounters (pp. 1-44). Oxford: Basil Blackwell.

Jawad, S. A. (2006). The Arab and Palestinian narratives of the 1948 war. In R. I. Rotberg (Ed.), Israel and Palestinian narratives of conflict: History's double helix (pp. 72-114). Bloomington, IN: Indiana University Press.

Kackowicz, A. M. (2004). Rashomon in the Middle East: Clashing narratives, images and frames in the Israel-Palestinians conflict. Cooperation and Conflict: Journal of the Nordic International Studies Association, 40(3), 343-360.

Kelman, H. C. (1999). The interdependence of Israeli and Palestinian national identities: The role of the other in existential conflicts. Journal of Social Issues, 55(3), 581-600.

Khoury, J., \& Hass, A. (2013, March 22). Abbas to Obama: Israel talks only in exchange for settlement freeze, release of prisoners. Haaretz. Retrieved from http://www.haaretz.com/news/obama-visits-israel/1.511369

Klar, Y. (2014). From "Do not arouse or awaken love until it so desires" through "Return to Zion" to "Conquest of the Land": Paradigm shifts and sanctified reenactments in building the Jewish State. International Journal of Intercultural Relations, 43, 87-99.

Klar, Y., Schori-Eyal, N., \& Klar, Y. (2013). The Never Again State of Israel: The emergence of the Holocaust as a core feature of Israeli identity and its four incongruent voices. Journal of Social Issues, 69(1), 125-143. http://dx.doi.org/10.1111/josi.12007

László, J. (2013). Historical Tales and National Identity: An Introduction to Narrative Social Psychology. New York: Routledge.

László, J., Cserto, I., Fulop, E., Ferenczhalmy, R., Hargitai, R., Lendvai, P., et al. (2013). Narrative language as an expression of individual and group identity: The narrative categorical content analysis. SAGE Open, 3(2.) http://dx.doi.org/10.1177/2158244013492084

László, J., Ehmann, B., Pólya, T., \& Peley, B. (2007). Narrative psychology as science. ETC: Empirical Text and Culture Research, $3,1-13$.

Liu, J. H., Fisher-Onar, N., \& Woodward, M. W.(2014). Symbologies, technologies, and identities: Critical junctures theory and the multi-layered nation-state. International Journal of Intercultural Relations, 43, 2-12.

Liu, J. H., \& Hilton, D. J. (2005). How the past weighs on the present: Social representations of history and their role in identity politics. British Journal of Social Psychology, 44(4), 537-556. http://dx.doi.org/10.1348/014466605X27162

Liu, J. H., \& László, J. (2007). A narrative theory of history and identity: Social identity, social representations, society and the individual. In G. Moloney, \& I. Walker (Eds.), Social representations and identity: Content, process and power (pp. 85-107). London: Palgrave-Macmillan.

Maoz, I. (2000a). Multiple conflicts and competing agendas: A framework for conceptualizing structured encounters between groups in conflict-The case of a coexistence project of Jews and Palestinians in Israel. Peace and Conflict: Journal of Peace Psychology, 6(2), 135-156.

Maoz, I. (2000b). Power relations in intergroup contact encounters: A case study of Jewish-Arab encounters in Israel. International Journal of Intercultural Relations, 24, 259-277

Maoz, I. (2001). Participation, control, and dominance in communication between groups in conflict: Analysis of dialogues between Jews and Palestinians in Israel. Social Justice Research, 14, 189-208

Maoz, I. (2011). Does contact work in protracted asymmetrical conflict? Appraising 20 years of reconciliation-aimed encounters between Israeli Jews and Palestinians. Journal of Peace Research, 48(1), 115-125.

Maoz, I., Bar-On, D., Bekerman, Z., \& Jaber-Massarwa, S. (2004). Learning about good enough through bad enough: A story of a planned dialogue between Israeli Jews and Palestinians. Human Relations, 57(9), 1075-1101. http://dx.doi.org/10.1177/0018726704047139

Maoz, I., Steinberg, S., Bar-On, D., \& Fakhereldeen, M.(2002). The dialogue between the self and the other: A process analysis of Palestinian-Jewish encounters in Israel. Human Relations, 55(8), 931-962.

McAdams, D. P. (2006). The redemptive self: Stories Americans live by. New York: Oxford University Press.

Morris, B. (1989). The birth of the Palestinian refugee problem, 1947-1949. Cambridge, England: Cambridge University Press.

Nets-Zehngut, R. (2008). The Israeli National Information Center and collective memory of the Israeli-Arab conflict. Middle East Journal, 62(4), $653-670$

Nets-Zehngut, R. (2011). Palestinian autobiographical memory regarding the 1948 Palestinian exodus. Political Psychology, 32(2), 271-295. http://dx.doi.org/10.1111/j. 1467-9221.2010.00807.x

Noor, M., Shnabel, N., Halabi, S., \& Nadler, A. (2012). When suffering begets suffering: The psychology of competitive victimhood between adversarial groups in violent conflicts. Personality and Social Psychology Review, 16(4), 351-374. http://dx.doi.org/10.1177/1088868312440048

Oren, N., \& Bar-Tal, D. (2007). The detrimental dynamics of delegitimization in intractable conflicts: The Israeli-Palestinian case. International Journal of Intercultural Relations, 31(1), 111-126.

Pappé, I. (2007). The ethnic cleansing of Palestine. Oxford, UK: Oneworld.

Pettigrew, T. F. (1998). Intergroup contact theory. Annual Review of Psychology, 49, 65-85.

Pettigrew, T. F. (2008). Future directions for intergroup contact theory and research. International Journal of Intercultural Relations, 32, 187-199. http://dx.doi.org/10.1016/j.ijintrel.2007.12.00

Pettigrew, T. F., \& Tropp, L. R. (2006). A meta-analytic test of intergroup contact theory. Journal of Personality and Social Psychology, 90(5), $751-778$.

Pilecki, A., \& Hammack, P. L. (2013). Victims versus righteous victims: The rhetorical construction of social categories in historical dialogue among Israeli and Palestinian youth. Political Psychology, http://dx.doi.org/10.1111/pops.12063

Potter, J., \& Wetherell, M. (1995). Discourse analysis. In J. A. Smith, R. Harré, \& L. van Langenhove (Eds.), Rethinking methods in psychology (pp. 80-92). London: Sage.

Rodinson, M. (1973). Israel: A colonial-settler state? New York: Pathfinder.

Ron, Y., \& Maoz, I. (2013). Dangerous stories: Encountering narratives of the other in the Israeli-Palestinian conflict. Peace and Conflict: Journal of Peace Psychology, 19(3), 281-294. http://dx.doi.org/10.1037/a0033686

Ron, Y., Maoz, I., \& Bekerman, Z. (2010). Dialogue and ideology: The effect of continuous involvement in Jewish-Arab dialogue encounters on the ideological perspectives of Israeli-Jews. International Journal of Intercultural Relations, 34(6), 571-579. http://dx.doi.org/10.1016/j.ijintrel.2010.07.001

Rotberg, R. I. (Ed.). (2006). Israeli and Palestinian narratives of conflict: History's double helix. Bloomington, IN: Indiana University Press.

Rouhana, N. N. (2004). Group identity and power asymmetry in reconciliation processes: The Israeli-Palestinian case. Peace and Conflict: Journal of Peace Psychology, 10(1), 33-52

Rouhana, N. N., \& Bar-Tal, D. (1998). Psychological dynamics of intractable ethnonational conflicts: The Israeli-Palestinian case. American Psychologist, 53(7), $761-770$.

Sa'di, A. H., \& Abu-Lughod, L. (Eds.). (2007). Nakba: Palestine, 1948, and the claims of memory. New York: Columbia University Press.

Said, E. W. (1979). The question of Palestine. New York: Vintage.

Said, E. W. (1994). The politics of dispossession: The struggle for Palestinian self-determination, 1969-1994. New York: Vintage.

Saguy, T., \& Dovidio, J. F. (2013). Insecure status relations shape preferences for the content of intergroup contact. Personality and Social Psychology Bulletin, 39(8), 1030-1042. http://dx.doi.org/10.1177/0146167213487078 
Saguy, T., Chernyak-Hai, L., Andrighetto, L., \& Bryson, J. (2013). When the powerful feels wronged: The legitimization effects of advantaged group members' sense of being accused for harboring racial or ethnic biases. European Journal of Social Psychology, 43(4), 292-298, doi:http://dx.doi.org/10.1002/ejsp.1948.

Saguy, T., Dovidio, J. F., \& Pratto, F. (2008). Beyond contact: Intergroup contact in the context of power relations. Personality and Social Psychology Bulletin, 34(3), 432-445, doi:http://dx.doi.org/10.1177/0146167207311200.

Sherif, M. (1958). Superordinate goals in the reduction of intergroup conflict. American Journal of Sociology, 63(4), 349-356.

Shnabel, N., \& Nadler, A. (2008). A needs-based model of reconciliation: Satisfying the differential emotional needs of victim and perpetrator as a key to promoting reconciliation. Journal of Personality and Social Psychology, 94(1), 116-132. http://dx.doi.org/10.1037/0022-3514.94.1.116

Steinberg, S., \& Bar-On, D. (2002). An analysis of the group process in encounters between Jews and Palestinians using a typology for discourse classification. International Journal of Intercultural Relations, 26(2), 199-214.

Suleiman, R. (2004). Planned encounters between Jewish and Palestinian Israelis: A social-psychological perspective. Journal of Social Issues, 60(2), 323-338.

Tajfel, H., \& Turner, J. C. (1986). The social identity theory of intergroup behavior. In S. Worchel, \& L. W. Austin (Eds.), Psychology of intergroup relations (pp. 7-24). Chicago: Nelson-Hall.

Tappan, M. B. (1997). Interpretive psychology: Stories, circles, and understanding lived experience. Journal of Social Issues, 53(4), 645-656.

Tessler, M. (1994). A history of the Israeli-Palestinian conflict. Bloomington, IN: Indiana University Press.

Trope, Y., \& Liberman, N. (2000). Temporal construal and time-dependent changes in preference. Journal of Personality and Social Psychology, 79(6), 876-889. http://dx.doi.org/10.1037//0022-3514.79.6.876

Vollhardt, J. R. (2009). The role of victim belief in the Israeli-Palestinian conflict: Risk or potential for peace? Peace and Conflict: Journal of Peace Psychology, 15(2), 135-159.

Wohl, M. J. A., \& Branscombe, N. R. (2008). Remembering historical victimization: Collective guilt for current ingroup transgressions. Journal of Personality and Social Psychology, 94(6), 988-1006. http://dx.doi.org/10.1037/0022-3514.94.6.988

Zembylas, M., \& Bekerman, Z. (2008). Education and the dangerous memories of historical trauma: Narratives of pain, narratives of hope. Curriculum Inquiry, 38(2), 125-154. http://dx.doi.org/10.1111/j.1467-873X.2007.00403.x 